University of Nebraska - Lincoln

DigitalCommons@University of Nebraska - Lincoln

Journal for the Advancement of Developing Institute for the Advancement of Developing Economies

Economies

2021

\title{
Profit Efficiency Analysis of Cassava Production in Enugu State,
} Nigeria

\author{
Oguejiofor J. Okorie \\ University of Nigeria \\ Ubokudom E. Okon \\ Akwa Ibom State University, Nigeria, ubokudomokon@aksu.edu.ng \\ Anselm A. Enete \\ University of Nigeria
}

Follow this and additional works at: https://digitalcommons.unl.edu/jade

Part of the Econometrics Commons, Growth and Development Commons, International Economics Commons, Political Economy Commons, Public Economics Commons, and the Regional Economics Commons

Okorie, Oguejiofor J.; Okon, Ubokudom E.; and Enete, Anselm A., "Profit Efficiency Analysis of Cassava Production in Enugu State, Nigeria" (2021). Journal for the Advancement of Developing Economies. 46. https://digitalcommons.unl.edu/jade/46

This Article is brought to you for free and open access by the Institute for the Advancement of Developing Economies at DigitalCommons@University of Nebraska - Lincoln. It has been accepted for inclusion in Journal for the Advancement of Developing Economies by an authorized administrator of DigitalCommons@University of Nebraska - Lincoln. 


\title{
Profit Efficiency Analysis of Cassava Production in Enugu State, Nigeria
}

\author{
Oguejiofor J. Okorie ${ }^{1}$, Ubokudom E. Okon ${ }^{2 *}$, Anselm A. Enete ${ }^{1}$ \\ ${ }^{1}$ Department of Agricultural Economics, University of Nigeria, Nsukka, Enugu State, Nigeria \\ ${ }^{2}$ Department of Agricultural Economics and Extension, Akwa Ibom State University, Nigeria
}

\begin{abstract}
This study analyzed the profit efficiency of smallholder cassava farmers in Enugu state, Nigeria. The study employed a multi-stage random sampling technique in selecting 240 cassava farm households who are registered in the Enugu State Fadama III project during the 2019 farming season. Data were collected using copies of structured questionnaire and interview schedule. Collected data were analyzed using descriptive and inferential statistics (stochastic frontier profit function model). Results showed that the majority (73.3\%) of the household heads were male, with a mean age of 52 years. Additionally, the majority (78.5\%) of the respondents were married, mean farm size of respondents was 0.3125 ha, mean duration of formal schooling was 9 years, and personal savings was the major (83.1\%) source of capital among respondents. The results further showed that profit efficiency ranged between 34.19 and $99.98 \%$, while mean efficiency was $73 \%$ with the $27 \%$ loss in profit attributed to a combination of technical and allocative inefficiencies. Also, educational level and years of farming experience were the major significant factors which influence profit efficiency positively. Findings from this study could be relevant for policy formulation by government.
\end{abstract}

Keywords: West Africa, crop productivity, determinants, frontier, small-scale farm *Corresponding author: ubokudomokon@aksu.edu.ng / +2348030757061

JEL Classification: D10, D13, D24

\section{INTRODUCTION}

The majority of food insecure persons in the world are rural smallholder farmers who are predominantly inhabitants of developing countries. Sub-Sahara Africa (SSA) comprises of about $23.8 \%$ of the food insecure people (Tesema \& Berhanu, 2018). As a result, smallholder farms are critical to food security and the livelihood of rural farmers. The various strategies farmers follow to produce food and generate income from their on-farm and off-farm activities determine food security (International Food Policy Research Institute [IFPRI], 2015). Food security is the basic right of people to produce and/or purchase the food they need in order to eradicate hunger and poverty (Sustainable Development Goals 1 and 2) (Wijk et al., 2018; IFPRI, 2015). Alliance for a Green Revolution in Africa, AGRA (2017) reports indicated that 500 million smallholder farms around the world provide livelihoods for more than 2 billion persons and that smallholders produce about $80 \%$ of the food in SSA and Asia. However, about 214 million persons in SSA suffer from chronic hunger against SDG 2 (Food and Agriculture Organization of the United Nations [FAO], 2015). 
Global production of cassava amounted to about 278 million metric tons in 2018 out of which Africa's share was put at about 61\% (Food and Agriculture Organization Corporate Statistical Database [FAOSTAT], 2020). In Nigeria, cassava is one of the fastest expanding staple food crops. Cassava crop has continued to gain prominence among farmers in Nigeria while the industrial demand is also rising consistently (FAO, 2018). In 2020, Nigeria's cassava production was put at about 42.5 million metric tons which is estimated to be about $18 \%$ of global production. Nigeria's share of the world production rose to $21.5 \%$ of the world production by 2018 (FAOSTAT, 2020). According to (FAOSTAT, 2020), it is projected that by the year 2025, about $62 \%$ of global cassava production will be from SSA. This will only be possible if farmers in SSA and Nigeria in particular are efficient in their resource utilization.

Despite a key role that cassava plays in guaranteeing household food security in Nigeria, small scale cassava farmers in Nigeria face diverse constraints, while resources to satisfy the constraint are scarce. The potential of cassava to contribute to national development is challenged by low adoption and use of improved technologies, climate variability, poor agronomic practices, inefficient use of production resources, low productivity, etc. The need to raise productivity is an important aspect of economic growth because it considers the extent to which output could be increased with given levels of resources. Particularly, productivity growth of cassava in the Southeast geopolitical zone reflects the country's ability to feed an ever-increasing population despite the constraints that the country faces.

The cassava sector is important for household and national income as well as food security. Several farm-level efficiency studies on cassava production have been conducted in Nigeria. There has been limited information on profit efficiency of cassava production in the study area. This study therefore aims at estimating profit efficiency among cassava farmers in the study area. We hypothesized that some socio-economic factors of the cassava farmers have influence on their profit efficiency in the study area. Information on these can provide a useful insight into reducing food insecurity and poverty in Nigeria.

\section{METHODOLOGY}

\subsection{Study Area}

The study area was Enugu State, Nigeria. According to Ezike (1998), the state is located between longitudes 60351 and 70301E, latitudes 60301 and 70101N of Greenwich Meridian. Enugu State shares boundary in the east with Ebonyi State, Benue and Kogi States in the north, Abia State in the south and Anambra State in the west. It occupies an area of about 8,022.95 km2 (Ezike, 1998) and has a population of 4,411,119 people (National Bureau of Statistics [NBS], 2017). Enugu State is made up of 17 local government areas (LGAs) and it is divided into three agricultural zones namely: Enugu Zone comprising Enugu East, Enugu North, Ezeagu, Igbo-Etiti and Udi LGAs; Awgu Zone comprising Awgu, Aninri, Enugu South, Nkanu East, Nkanu West and Oji-River LGAs; Nsukka Zone comprising Igbo-Eze South, Isi-Uzo, Nsukka, Udenu, Uzo-Uwani, Igbo-Etiti LGAs (Enugu State Agricultural Development Programme, ENADEP, 1997).

Enugu State has a tropical climate with a characteristically high temperature all year round. The state enjoys two distinct seasons, namely, rainy (April to October) and dry (November to March) 
seasons, respectively. The climate supports the growing of the following crops: yam, cassava, oil palm, cashew, cocoa, vegetables, maize, rice, etc. A farmer can rear animals of different species for consumption and sales (Nigerian Meteorological Agency [NiMET], 2013).

\subsection{Sampling Procedure}

A multi-stage random sampling technique was used in selecting the smallholder farming households from a list of 18,200 registered farming households in the Enugu State Fadama Coordinating Office. In the first stage, two zones were randomly selected out of the three agricultural zones in the state. In the second stage, three (3) LGAs were randomly selected from each of the two selected Agricultural zones previously selected, making a total of six (6) LGAs. In the third stage, four (4) rural communities were then randomly selected from the list of communities in each LG Fadama desk office, making a total of twenty-four rural communities for the study. In the fourth stage, ten (10) households were randomly selected from a list of households in the selected rural communities. In all, a total of two hundred and forty (240) farm households were sampled. However, twenty-one (21) copies of structured questionnaires were either not returned or not completed. In the end, two hundred and nineteen (219) copies of the questionnaires were used in the study.

\subsection{Method of Data Collection}

Data collection was essentially from primary sources and included the following variables: age (years), educational level (years), farming experience (years), household size (numbers), farm size

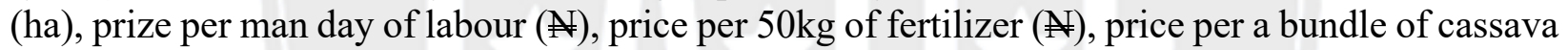
stem $(\AA)$, average price of farm tools $(N)$, income of household head ( $N$ ), average credit accessed $(\aleph)$, previous year's profit (gain=1, 0 otherwise), future year's expectation (gain=1, 0 otherwise), etc.

\subsection{Data Analysis}

Descriptive and inferential tools were employed to achieve the objectives of the study. The objectives were realized using stochastic profit frontier analysis.

\subsubsection{Efficiency Model}

Farrell (1957) developed a comparative production and cost possibility curve or frontier where the frontier is the best performer among the rest of the decision makers in either output or cost function. This comparative approach of productivity gave rise to the efficiency measurement of the decision makers. Since then, several approaches to efficiency measurement have emerged, namely, (1) parametric Stochastic Frontier Analysis (SFA) initially proposed by Aigner et al. (1977) and independently by Meeusen and Van den Broeck (1977); and (2) non-parametric Data Envelopment Analysis (DEA) initially developed by Charnes \& Cooper (1961).

However, the choice of either the SFA or DEA approach to measure efficiency has been a function of the objective of the research, the availability of data and the type of industry involved (Wadud \& White, 2000). Typical of nonparametric approach, (DEA) does not rely on the definition of a 
functional form underlying the technology and therefore avoids misspecification problems. However, the flaw of this technique is that it is deterministic and ignores the stochastic error term which connotes that deviations from the frontier are entirely attributed to inefficiency of the decision maker. Sequel to this, technical efficiency index obtained from the nonparametric approach are generally lower than those obtained under the parametric SFA approach (Coelli, 2005; Kumbhakar \& Lovell, 2000; Wadud \& White, 2000).

Unlike DEA, the econometric or parametric SFA approach incorporates a composed error structure with two-sided symmetric term and a one-sided component which aimed at distinguishing between inefficiency and exogenous shocks. The one-sided component reflects inefficiency while the twosided error captures the random effects and exogenous shocks outside the control of the decision maker. The second category of error in the structure includes measurement errors and other statistical noise typical of empirical relationships (Meeusen \& Van den Broeck, 1977). The twosided error allows for hypothesis testing and construction of confidence intervals (Wadud \& White, 2000). Unlike the DEA, SFA need to assume a functional form for the frontier technology and for the distribution of technical inefficiency term of the composite error term. Between the two approaches, the study adopts the stochastic frontier function approach since agricultural crop production exhibits random shocks and there is a need to separate the influence of stochastic factors from the effects of other inefficiency factors by assuming that deviation from the production frontier may not be entirely under the control of farmers. Economic applications of Stochastic Profit Frontier Model for Productions efficiency analysis include Adesina and Djato (1996) who applied the techniques in the study of the efficiency of rice farmers in Cote d' Ivoire and Ogundari (2006) who applied it on the determinants of profit efficiency among rice farmers in Nigeria.

\subsubsection{Stochastic Profit Frontier Analysis}

Profit efficiency in this study is defined as profit gain from operating on the profit frontier, taking into consideration farm-specific prices and factors. Also, considering a farm that maximizes profit subject to perfectly competitive input and output markets and a singular output technology that is quasi-concave in the ( $\mathrm{n} \times 1)$ vector of variable inputs, and the ( $\mathrm{m} \times 1)$ vector of fixed factors, $\mathrm{Z}$. The actual normalized profit function which is assumed to be well behaved can be derived as follows:

Farm profit is measured in terms of Gross Margin (GM) which equals the difference between the Total Revenue (TR) and Total Variable Cost (TVC). That is:

$$
G M(\Pi)=\sum(T R-T V C)=\sum\left(P Q-W X_{i}\right) .
$$

To normalize the profit function, gross margin ( $\Pi$ ) is divided on the both side of the equation above by $\mathrm{P}$ which is the market price of the output (cassava). That is:

$\frac{\Pi}{P}(p, z)=\frac{\sum\left(P Q-W X_{i}\right)}{P}=Q-\frac{W X_{i}}{P}=f\left(X_{i}, Z\right)-\Sigma p_{i} X_{i}$

Where TR represents total revenue, TVC represents total variable cost, $\mathrm{P}$ represents price of cassava output $(\mathrm{Q}), \mathrm{X}$ represents the quantity of optimized input used, Z represents price of fixed 
inputs used, $\mathrm{W}$ is a normalized function, $\mathrm{p}_{\mathrm{i}}=\mathrm{W} / \mathrm{P}$ which represents normalized price of input $\mathrm{X}_{\mathrm{i}}$ while $\mathrm{f}\left(\mathrm{X}_{\mathrm{i}}, \mathrm{Z}\right)$ represents production function.

The stochastic frontier profit function is an extension of the Cobb-Douglas by Coelli (1996) which specifies the inefficiency components and estimates all parameters together in one-step maximum likelihood estimation and is specified as follows:

Explicit function

$\Pi=\alpha+\beta 1 \mathrm{Z} 1+\beta 2 \mathrm{P} 1+\beta 3 \mathrm{P} 2+\beta 4 \mathrm{Z} 2+(\mathrm{V}-\mathrm{Ui})$

$\Pi=$ Gross margin

$\alpha=$ constant

$\beta i=$ elasticities,$i=1 \ldots . . n$

$Z_{1}$ represents average number of hectare (ha) put to use

$\mathrm{P}_{1}$ represents average price per man-day of labour $(\mathrm{N})$

$\mathrm{P}_{2}$ represents average price per $50 \mathrm{~kg}$ of fertilizer $(\mathrm{N})$

$\mathrm{Z}_{2}$ represents average output price (barrow) (

$\mathrm{V}$ represents error term

The inefficiency model $U_{i}$ is defined by:

$U_{i}=\alpha_{0}+\alpha_{1} M_{1 i}+\alpha_{2} M_{2 i}+\alpha_{3} M_{3 i}+\alpha_{4} M_{4 i}$

Where $\mathrm{M}_{1}, \mathrm{M}_{2}, \mathrm{M}_{3}, \mathrm{M}_{4}$ represent age (year), educational level (year), farming experience (year) and household size (number of persons), respectively. The socio-economic variables are included in the model to indicate their influence on the profit efficiencies.

If $\mathrm{U}_{\mathrm{i}}>0$, the farmer is inefficient and losses profit as a result.

The estimates of all the parameters of the stochastic profit function and the inefficiency model are simultaneously obtained using the program Frontier Version 4.1c (Coelli, 1996). The stochastic frontier model was simultaneously proposed by Aigner et al., (1977) and Meeusen and Van den Broeck (1977) who drew their works upon the Farell (1957) seminar paper on efficiency measurement in which he defined productive efficiency as the ability of a firm to produce a given level of output at lowest cost.

Broadly, three quantitative approaches are developed for measuring productive efficiency: Parametric (deterministic and stochastic), non-parametric based on Data Envelopment Analysis (DEA), and productivity indices based on growth accounting and index theory principles (Battese \& Coelli, 1998). Stochastic Frontier Analysis (SFA) and the DEA are the most used methods. Both methods estimate the efficiency frontier and calculate the firms' technical, cost and profit efficiency relative to it. The frontier shows the best performance observed among the firms and it is considered as the frontier production while DEA approach uses linear programming to construct a piecewise frontier that envelops the observation of all firms. An advantage of the DEA method is that multiple inputs and outputs can be considered simultaneously, and inputs and outputs can be quantified using different units of measurement. 
However, a strong point for SFA in comparison to DEA is that it takes into account measurement errors and other noise in the data. This point is very important for studies of farm level data in developing economy like Nigeria as data generally include measurement errors.

\section{RESULTS AND DISCUSSION}

\subsection{Summary Statistics on the Profit Efficiency of Cassava Enterprise in the Study Area}

Profit efficiency of factor inputs as cost of labour, farm size, cost of fertilizer, age of the farmer, educational level of the farmer, years of experience, and household size are discussed in the following section. The mean gross margin of $\$ 19,228.4$ and a standard deviation of $\$ 7,658.02$ were recorded. The revenue from cassava production was low because very few cassava farmers had access to fertilizer due to its high cost. The average farm size was 0.31 ha with a standard deviation of $0.38 \mathrm{ha}$. This revealed that land fragmentation is setting limits to agricultural activities. Given the caput profit and land for an average household size of 6 persons in the study area, cassava production cannot be pursued as a sole enterprise. In addition, the average output price of $\$ 1149.77$ with $\$ 423.91$ standard deviation per barrow load measure was recorded. The average price of fertilizer was $\$ 6,038$.81per bag with a standard deviation of $\$ 738$.77. The price of labor per production cycle of one year was comparatively stable with average of N977.63 and standard deviation of 212.67 . Years of experience with mean vale of 18 years showed that agriculture is the main source of livelihood for the respondents.

Table 1: Summary Statistics Results for Estimating Stochastic Profit Frontier Model

\begin{tabular}{lcccc}
\hline Variable & Min & Max & Mean & Standard Dev. \\
\hline Gross margin ( $N$ ) & 100.0 & $182,200.00$ & $19,228.40$ & $7,658,02$ \\
Average price of labour ( $¥$ ) & 600.00 & $1,800.00$ & 977.63 & 212.67 \\
Farm size (ha) & 0.01 & 2.0 & 0.31 & 0.38 \\
Output price ( $)$ & $3,700.00$ & $4,800.00$ & $4,279.77$ & 423.91 \\
Average price of fertilizer ( & $5,750.00$ & $6,900.00$ & $6,038.81$ & 738.77 \\
Age (year) & 20.0 & 50.0 & 43.0 & 10.70 \\
Education level (year) & 0.0 & 16.0 & 8.0 & 4.95 \\
Year of experience (year) & 1.0 & 56 & 18.70 & 10.99 \\
Household size (person) & 1.0 & 15.0 & 6.24 & 2.34 \\
\hline
\end{tabular}

Source: Field survey data, 2019. Note: US\$1 $=\$ 360.00$

\subsection{Socio-Economic Characteristics of the Respondents}

From the study, the socio-economic variables of the farmers influenced their decisions on farm size, enterprise diversity (mixed cropping), and production processes. As indicated in Table 2, the variables analyzed in the study are age, marital status, sex, level of education, farming experience, income level, household size and farm size.

The sex of respondents showed that the male constituted $73.5 \%$ of respondents while female accounted for $26.5 \%$ of the sample. It could be that cassava production requires more land area as 
men have more land rights than women hence women are into more of trading. The age distribution of respondents as shown in Table 2 showed that $56.2 \%$ of them fall within the age category of less or equal to 50 years, while $43.9 \%$ fall within the age category of greater than 50 yrs. The mean age was 52 years. This implies that young and vibrant people are still involved in cassava production. For marital status, $78.5 \%$ of respondents were married, $5.0 \%$ single, $3.7 \%$ widowed, and $11.9 \%$ divorced. Married heads of households are most likely to have available labour for cassava production.

Lipsey and Chrystal (2004) posited that a household comprised of all persons who live under the same roof and eat from the same pot and make a joint financial decision. For the purpose of this study, a household implies the head, wife or wives, children and other dependents that live under the same roof. From the survey, households with sizes ranging from 4-6 accounted for $46.12 \%$ of respondents. Those whose sizes ranged from 7-9 in number accounted for $36.53 \%$, the range of 1 3 persons accounted for $9.59 \%$ and the household range of $10-12$ and $13-15$ accounted for $6.9 \%$ and $1.37 \%$ of the respondents, respectively. The mean value of the number of persons per household was 6 .

Farm size is affected by many factors including household size, available arable land, level of capital of the farmer, among others (Kaindaneh, 2007). On the average, respondents had farm size of 0.3125 hectares. The majority $(79.9 \%)$ of the respondents had farms whose sizes ranged from 0.01 to 0.39 ha. This was followed by that of 0.42 to 0.74 ha representing $9.58 \%$. Farm size of range 1.5 to 2.0 ha was rare accounting for $1.85 \%$. The traditional land tenure system as practiced in the area has led to land fragmentation, hence reducing the size of land available for crop production by individual households (Ugwu \& Okoye, 2019). The farm size distribution also agrees with Brundtland commission categorization of agricultural system (WCED, 1987), which suggested that resource poor farmers generally had small farm units, fragile soil, minimum inputs and are rain dependent.

Surprisingly, $17.4 \%$ of the respondents had no formal education while $82.7 \%$ had one form of education or the other; primary education accounted for $34.7 \%$, secondary education, $41.1 \%$ while tertiary education was $6.9 \%$. The mean year of formal education was 9 years. This was in contradiction to Kaindaneh (2007) that farmers cultivating small farms are illiterate or uneducated. This implies that farmers in the area are relatively educated and hence likely to be receptive to new innovations and will easily adopt them for greater productivity. Also, Table 2 showed that $68.0 \%$ of the respondents had farming as primary occupation while $10.5 \%$ were traders, $15.1 \%$ were civil servants and $6.4 \%$ were artisan. This showed that the majority of the respondents engaged in farming for livelihood. Also, 3.7\% of the respondents acquired land through leasehold, 31.5\% rented land for farming activities, and 57.1\% acquired land through inheritance while $0.5 \%$ and $7.3 \%$ acquired land through exchange and communal method, respectively. This further suggested that the poor participation of women in cassava production was due to women's right to land as women do not inherit land in the area hence more vulnerable.

The majority (83.1\%) of the respondents' acquired capital through personal savings, $15.1 \%$ acquired through informal lenders, while those who acquired through government $(0.9 \%)$ and banks $(0.9 \%)$ were very few. This could mean that the respondent had no collateral securities to 
borrow from banks or that the banks interest rates were high. This suggests that the respondents may be under credit constraints.

The household income is a source of capital for farm operation. Family income may be channeled to any enterprise depending on the utility it provides to the household. Table 2 showed that out of the 219 respondents, $35.16 \%$ generated income within the range of $\$ 98,000.00$ to $\$ 255,000.00$ annually. While the income ranges of $\$ 260,000.00$ to $\$ 415,500.00$ accounted for $31.5 \%$ (exchange rate was $\$ 360$ Naira to US\$1 as at the time of this study). Respondents' information did not show the proportion of income accruing form off-farm activities. In general, fallow practices by respondents showed that $17.8 \%$ of the respondents grew cassava continually on a given plot of land while $82.2 \%$ grew it for a year or two and left the land to fallow for 1-4 years before coming back to it again. This is evidence that farm inputs are not available to encourage intensification. The fallow year is a period during which farmland is allowed to regenerate naturally so that land can continue to support future agricultural production. The fallow period could be affected by urbanization, population growth, availability of fertilizer and other agrochemicals, and the incidence of pest on the farm. The data showed that $49.8 \%$ of the farmers practiced a two-year fallow period. This was followed by periods of three- one-, and four-year fallow with $30.6,11.4$ and $8.2 \%$ of respondents, respectively. This suggests that the fallow years were short such that fertilizer addition may be required to keep farmers in production.

Table 2: Socio-Economic Characteristics of the Respondents

\begin{tabular}{lccc}
\hline Variables & Frequency & Percentage & Cum. Frequency \\
\hline Sex & & & \\
Male & 161 & 73.5 & 73.5 \\
Female & 58 & 26.5 & 100.0 \\
Age (mean = 52 years) & & & \\
$\leq 20$ & 2 & 0.9 & 0.9 \\
$21-30$ & 23 & 10.5 & 11.4 \\
$31-40$ & 49 & 22.4 & 33.8 \\
$41-50$ & 49 & 22.4 & 56.2 \\
$>50$ & 96 & 43.9 & 100.0 \\
Marital Status & & & \\
Married & 174 & 79.5 & 79.5 \\
Single & 11 & 5.0 & 84.5 \\
Divorced & 8 & 3.7 & 88.1 \\
Widowed & 26 & 11.9 & 100.0 \\
Education Level (mean $=9$ years) & & & \\
No formal education & 38 & 17.4 & 17.4 \\
Primary & 76 & 34.7 & 51.1 \\
Junior Secondary & 9 & 8.7 & 60.7 \\
Senior Secondary & 71 & 32.4 & 93.2 \\
Tertiary & 15 & 6.9 & 100.00 \\
Primary Occupation & & & \\
Farming & 149 & 68.0 & 78.5 \\
Trading & 23 & 10.5 & \\
& & & \\
\hline
\end{tabular}


Variables

Civil Servant

Artisan

Land Acquisition

Leasehold

Rent

Exchange

Inheritance

Communal

\section{Capital Acquisition}

Government

Personal saving

Banks

Informal lenders

Household Size $($ mean $=6$ years $)$

1-3

4-6

$7-9$

$10-12$

13-15

Farm Size $($ mean $=0.3125$ ha)

0.01-0.39

$0.40-0.74$

$0.75-1.17$

$1.18-1.50$

$>1.5 \leq 2.0$

Household Income $($ mean $=\mathbf{\$ 3 8 4 , 7 0 0})$

\section{Frequency}

1.75

738,000-890,000

Fallow practice

Continuous cropping

Fallow practice (1-4 years)

Fallow Year

One year

Two years

Three years

Four years
33

14

8

69

1

125

16

2

182

2

33

21

101

80

14

3

21

8

11

4

77

68

45

17

12

\section{Percentage}

15.1

6.4

3.7

31.5

0.5

57.1

7.3

0.9

83.1

0.9

15.1

9.59

46.12

36.53

6.39

1.37

79.9

9.58

3.65

6.02

1.83

35.16

31.05

20.55

7.76

5.48

39

180

25

109

67

18

17.8

82.2

\section{Cum. Frequency}

93.6

100.0

3.7

35.2

35.6

92.7

100.0

0.9

84.0

84.9

100.0

9.59

55.71

92.24

98.63

100.0

79.9

89.48

93.13

98.15

100.0

35.16

66.21

86.72

94.52

100.0

17.8

100.0

Source: Field Survey, 2019 


\subsection{Maximum Likelihood Estimation of the Parameters of the Stochastic Profit Frontier Model}

The estimated parameters of the normalized profit function based on the assumption of competitive market and a rational producer were negative except for fertilizer that was positive (Table 3 ).

Table 3: Maximum Likelihood Estimates of the Stochastic Profit Frontier Function

\begin{tabular}{|c|c|c|c|}
\hline Variable & Parameters & Model 1 & Model 2 \\
\hline Constant & $\mathrm{B}_{0}$ & $\begin{array}{c}3.3853 * * * \\
(7.2052)\end{array}$ & $\begin{array}{l}3.212 * * * \\
(10.37951)\end{array}$ \\
\hline Farm size & $\mathrm{B}_{1}$ & $\begin{array}{l}-0.005530 \\
(0.189279)\end{array}$ & $\begin{array}{l}-0.2856^{* *} \\
(2.704912)\end{array}$ \\
\hline Average price of labor & $\mathrm{B}_{2}$ & $\begin{array}{c}0.0974469 \\
(0.80722)\end{array}$ & $\begin{array}{c}-0.003110789 \\
(0.119733)\end{array}$ \\
\hline Average price of fertilizer & $\mathrm{B}_{3}$ & $\begin{array}{c}0.003268 \\
(0.086741)\end{array}$ & $\begin{array}{c}0.041296 * * * \\
(4.4423)\end{array}$ \\
\hline Inefficiency & & & \\
\hline Constant & $\alpha_{0}$ & 0 & $\begin{array}{r}-0.348850 \\
(0.37534)\end{array}$ \\
\hline Age (years) & $\alpha_{1}$ & 0 & $\begin{array}{l}0.0526978^{* *} \\
(2.27415)\end{array}$ \\
\hline Educational level (year) & $\alpha_{2}$ & 0 & $\begin{array}{c}-0.268489 * \\
(2.15022)\end{array}$ \\
\hline Year of experience (year) & $\alpha_{3}$ & 0 & $\begin{array}{l}-0.6975 * * \\
(3.18980)\end{array}$ \\
\hline Household size (person) & $\alpha_{4}$ & 0 & $\begin{array}{c}-0.0179547 \\
(0.28980)\end{array}$ \\
\hline Variance & & & \\
\hline Sigma square & & 0.238 & $\begin{array}{c}02253 * * * \\
(3.8672)\end{array}$ \\
\hline Gamma & HHACEH & $\square[0$ & $.99 * *(45.6727)$ \\
\hline Log likelihood ratio & 11LLI' & 47.653923 & 65.7198 \\
\hline
\end{tabular}

Source: Field survey, 2019

Figures in parenthesis are t-ratio

* Estimate is significant at $\mathrm{p}<10 \%$

$* *$ Estimate is significant at $\mathrm{p}<5 \%$

$* * *$ Estimate is significant at $\mathrm{p}<1 \%$

The study also showed that there was a presence of profit inefficiency effects among cassava farmers in the study area as indicated by gamma $(\gamma)(0.99)$. This was confirmed by a test of hypothesis for the presence of inefficiency effects using the generalized likelihood ratio test and significance of gamma $(\gamma)$ estimate (45.6727). The generalized likelihood ratio difference which is defined by the chi-squared $\left(x^{2}\right)$ distribution shows that the computed chi square value of 18.0659 
was significant at $\mathrm{p}<5 \%$. The null hypothesis was strongly rejected leading to the preference of model 2. Furthermore, the estimated gamma of model $2(0.99)$ was highly significant at $p<1 \%$ error indicating that about $99 \%$ of the variation in actual profit arose from the difference in farmers' socioeconomic variables rather than random variability.

The coefficient of fertilizer (0.041296) was positive and significant at the $1 \%$ level (Table 3), suggesting that the majority of the farmers in the study area used fertilizer to improve output. Farm size was negative and statistically significant at the $5 \%$ level of probability. This may be because of the level of poverty among the farmers. Poor farm households are usually undercapitalized (Enete \& Achike, 2008) and hence may not proportionately increase other inputs as farm size is increased.

The inefficiency model showed that the signs and significance of the estimated coefficients in the model have an important implication on the profit efficiency of farmers. Based on this, all variables in the inefficiency model have negative coefficients excerpt for age which was positive. This implies that profit efficiency of the cassava farmers increases with an increase in educational level and years of farm experience. Similarly, the profit inefficiency increases with the age of farmers. The implication of this findings is that many years of educational attainments enhances the acquisition of information on improved technologies and innovations (Okon et al., 2010). In addition, more experienced cassava farmers attained higher level of profit, while older farmers were inefficient, suggesting that profit inefficiency increases with age. This result is expected due to degenerating effect of age (senescence). The relationship with age and inefficiency observed in this study agrees with the work of Abdulail and Huffman (1998). While the negative coefficients of educational level, years of experience and household size were consistent with the work of Ogundari (2006). Variance Inflation Factor (VIF) was used to test for multicollinearity among the seven explanatory variables. The results showed a mean VIF of 1.457, suggesting the absence of multicollinearity among the independent variables. The independents variables with VIF values greater than $5(\mathrm{VIF}>5)$ could be contributing considerably to multicollinearity (Catterjee \& Simonoff, 2013).

Table 4: Profit Efficiency Performance Categories

\begin{tabular}{ccccccc}
\hline $\begin{array}{l}\text { Efficiency } \\
\text { range }\end{array}$ & $\begin{array}{c}\text { No of } \\
\text { respondents }\end{array}$ & \multicolumn{2}{l}{ Minimum Maximum } & Mean & Std. Deviation & Percentage \\
\hline 1 & 3 & .34194 & .40407 & .3730040 & .04393396 & 1.37 \\
2 & 17 & .44131 & .51475 & .4844899 & .02424705 & 7.76 \\
3 & 26 & .53180 & .60834 & .5760234 & .02619319 & 11.87 \\
4 & 37 & .61234 & .69148 & .6563176 & .02575755 & 16.89 \\
5 & 55 & .69269 & .77242 & .7336940 & .02256353 & 25.11 \\
6 & 36 & .77304 & .84745 & .8059090 & .02370221 & 16.44 \\
7 & 33 & .85602 & .93521 & .8981912 & .02406724 & 15.07 \\
8 & 12 & .94719 & .99983 & .9799411 & .01514320 & 5.48 \\
\hline
\end{tabular}

Source: Field Survey data, 2019 


\subsection{Efficiency Categories of Cassava Farmers in Enugu State, Nigeria}

Table 4 shows that the efficiency of farmers from the frontier analysis ranges from $34.19 \%$ to $99.98 \%$ with a mean of $72.94 \%$. This showed that the system has potentials to increase profit by $27.06 \%$ from cost reduction on resources when producing at efficient level. The most efficient category ranges from 94.719 to $99.983 \%$ efficient and accounted for $5.48 \%$ of the respondents while $70.31 \%$ of the respondents (about 154 of the cassava farmers) were between 57.60 to $80.59 \%$ efficient range which underscores the need for intervention by government by providing subsidized input for cassava production in the study area.

\subsection{Cropping System of Respondents}

Cassava was not grown as a sole crop in the study area. Different crops were intercropped with cassava. Table 5 showed that some (38.3\% of respondents) intercrop cassava with maize and yam while some other farmers include melon and cocoyam in cassava-based intercrop. About $17 \%$ of the respondents combine cassava with maize and melon in an intercrop. These practices are evident among smallholder farmers to avoid crop failure, consumption smoothing and income spread.

\section{Table 5: Distribution of Cassava-Based Intercrop in the Study Area}

\begin{tabular}{lcc}
\hline Cassava Base & No of Respondent & Percent \\
\hline + maize + yam & 84 & 38.3 \\
+ yam + maize + melon & 64 & 29.2 \\
maize + yam + cocoyam & 34 & 15.5 \\
+ melon + maize & 37 & 16.9 \\
\hline Total & $\mathbf{2 1 9}$ & $\mathbf{1 0 0 . 0}$ \\
\hline
\end{tabular}

Source: Field Survey data, 2019

\section{CONCLUSION AND RECOMMENDATIONS}

This study analyzed the profit efficiency of cassava production by smallholder cassava farmers in Enugu State, Nigeria. Data obtained were analyzed using stochastic frontier profit function. The majority of the farmers were educated with a mean of 9 years of formal schooling. The mean age of farmers was 52 years. Mean farm size was 0.3125 ha and mean household size was 6 persons. Major factors influencing profit efficiency in cassava production were farm size, price of fertilizer, age of the household heads, educational level, and farming experience. The distribution of profit indices showed that cassava farmers in the study area were fairly efficient in their resource allocation based on the mean farm specific efficiency of about $73 \%$.

Farm size had a negative correlation with profit efficiency. This means that profit efficiency reduces as farm size increases. Policies that could encourage farmers to intensify cassava production on their existing farm could lead to increase in profit. Perhaps, expanding farm size may be difficult due to land tenure system practiced in the study area. Also, average price of fertilizer had a positive correlation with profit efficiency, implying that profit efficiency increases with increase in fertilizer price. This means that for farmers to be profit efficient, they must 
increase the unit cost of cassava output. Provision of fertilizer subsidies to cassava farmers could reduce the unit cost of cassava as well as increase profit efficiency of farmers. The study also shows that age had a positive correlation with profit inefficiency. This means that aged farmers were more profit inefficient than younger farmers, implying that policies that will encourage younger people into cassava production could help in addressing profit inefficiency problems in the study area. Educational level had a negative correlation with profit inefficiency. Cassava farmers in the study area should register in adult education centers to improve their efficiency. Years of farming experience had a negative relationship with profit inefficiency. This means that profit efficiency increased with increase in years of farming experience. It is recommended that experienced farmers be encouraged to intensify cassava production.

\section{REFERENCES}

Abdulail, A., \& Huffman, W. E. (1998). An examination of profit inefficiency of rice farmers in Northern Ghana. Working paper in the Department of Economics, Iowa State University, Ames, U.S.A.

Adesina, A. A., \& Djato, K. K. (1996). Farm size, relative efficiency and agrarian policy in Côte d'Ivoire: Profit function analysis of rice farms. Agricultural Economics, 14(2), 93-102.

Africa Agriculture Status Report [AGRA] (2017). The business of smallholder agriculture in sub-Saharan Africa (Issue 5). Nairobi, Kenya: Alliance for a Green Revolution in Africa (AGRA). Issue No. 5.

Aigner, D.J., Lovell, C.A.K, \& Schmidt, P. (1977). Formulation and estimation of stochastic frontier production function models. Journal of Econometrics, 6(2), 21-37.

Alpizar, F., Saborio-Rodriguez, M., Martinez-Rodriguez, M. R., Viguera, B., Vignola,R., Capitan, T., \& Harvey, C.A. (2020). Determinants of food insecurity among smallholder farm households in Central America: recurrent versus extreme weather-driven events. Regional Environmental change (2020) 20:22 http:/doi.org/10.1007/s10113-020-01592$\mathrm{y}$.

Berger, A.N., \& Mester, L.J. (1997). Inside the black box: What explains differences in the efficiencies of financial institutions. Journal of Banking and Finance, 21,895-947.

Battese, G.E., \& Coelli, T.J. (1988). Prediction of firm-level technical efficiencies with generalised frontier production function and panel data. Journal of Econometrics, 38, 387-399.

Bowman, M.S., \& Zilberman, D. (2013). Economic factors affecting diversified farming system, Ecology and Society. 18 (1)B2 https://dx.doi.org/10.5751/ES-05574-180133.

Charnes, A., \& Copper, W.W., (1961). Management models and industrial applications of linear programming, Vol.1and 2. Wiley \& Sons.

Chatterjee, S., \& Simonoff, J.S. (2013). Handbook of regression analysis. Wiley \& Sons.

Coelli, T.J. (1996). A guide to Frontier Version 4.1c. A Computer Program for Stochastic Frontier Production and Cost Function Estimation, Mimeo, Department of Econometrics, University of New England, Armidala, Australia.

Culas, R., \& Mahendrarajah, M. (2005). Causes of diversification in agriculture overtime: evidence from Norwegian farming sector. International Congress, August 23-27. Copenhagen, Denmark 24647. European Association of Agricultural Economist. https//ideas.repec.org/p/ags/eaae05/24647html.

ENADEP (1997). Enugu State Agricultural Development Programme Reports. 
Enete, A.A., \& Achike, A. I. (2008). Urban agriculture and urban food insecurity/poverty in Nigeria: the case of Ohafia, South-east, Nigeria In: Outlook on Agriculture, Vol. 37, number 2.

Ezike, J.O. (1998). Delineation of old and new Enugu State. Unpublished Bulletin on land and survey, Ministry of Works, Enugu.

Farrel, J.M. (1957). The measurement of productive efficiency. Journal of Royal stats, 120, part III pp253-290.

Fawole, O, P., \& Oladele, I.O. (2007). "Sustainable food crop production through multiple cropping patterns among farmers in South-western Nigeria". Department of Agricultural Economics and Rural Development. University of Ibadan.

Food and Agricultural Organization [FAO] (2015): Livelihood diversification and vulnerability to poverty in rural Malawi. ESA working Paper No 15- 02.

Food and Agriculture data [FAOSTAT] (2020). Agricultural investment and capital stock 20002020 (Global and regional trend). Accessed 12 ${ }^{\text {th }}$ September, 2021 from https://www.fao.org.

Idiong, I. C. (2007). Estimation of farm level technical efficiency in Small-scale swamp rice production in Cross River State of Nigeria: A stochastic frontier approach. World Journal of Agricultural Sciences, 3(5), 653 - 658.

International Food Policy Research Institute [IFPRI] (2015). Global Nutrition Report 2015: Actions and accountability to advance nutrition and sustainable development. Washington, DC.

Kaindaneh, P.M. (2007). Technology Transfer from the Adaptive Crop Research and Extension Project in Sierra Leone. www.idrc.ca/technology Adaptive\%20.

Kumbhakar, S.C., \& Lovell, C.A.K. (2000). Stochastic Frontier Analysis. Cambridge University Press.

Lipsey, R.G., \& Chrystal, K. A. (2004). Economics : Tenth Edition (First Indian Edition). Manzar Kahn, Oxford University Press, YMCA Library Building, Jai Singh.

Maudos, J., Pastor, J. M., Perez, F., \& Quesada, J. (2002). Cost and profit efficiency in European banks. Journal of International Financial Markets, Institutions and Money, 12(1), 33-58.

Meeusen, W., \& Van Den Broeck, J. (1977). Efficiency estimation from Cobb-Douglas production functions with composed error. International Economic Review, 18, 435-444.

National Bureau of Statistics (NBS) (2017). Demographic Statistics Bulletin, Abuja, Nigeria

Ndubuizu, T.O.C. (1990). The Subsistence Crop Grower, In: Challenges of Agriculture in National Development. Ikeme (ed) Optimal Computer Solution Ltd.

Nweke, F. (2004). New Challenges in the cassava transformation in Nigeria and Ghana, International Food Policy Research Institute, Washington DC, USA. www.ifpri.org.

Nigerian Meteorogical Agency (NiMet) (2013). Nigerian Climate Review Bulletin, Abuja, Nigeria.

Ogundari, K. (2006). Determinants of profit efficiency among small scale rice farmers in Nigeria: A profit function approach. Poster paper prepared for presentation at the International Association of Agricultural Economists Conference, Gold Coast, Australia, August 1218.

Okon, U. E., Enete, A. A., \& Bassey, N. E. (2010). Technical efficiency and its determinants in garden egg (Solanum Spp) production in Uyo Metropolis, Akwa Ibom State, Nigeria. Field Actions Science Report, www.factsreports.org. 
Okorie, O. J., Omeje, E. E., \& Awoyelu, F.E. (2019). Constraints to adoption of innovations by cassava farmers in Enugu State, Nigeria. AKSU Journal of Agricultural Economics, Extension and Rural Development, 2(2), 73-83.

Oladele, O. I. (2005). A Tobit analysis of propensity to discontinue adoption of agricultural technology among farmers in Southwestern Nigeria. Journal of Central European Agriculture, 6(3), 249-254.

Olagoke, A.M. (1990). Comparative Economics of Resources use in Rice and Yam-Based Crop Production in Uzo-Uwani Local Government Area of Anambra State Unpublished Ph.D Thesis, University of Nigeria, Nsukka.

Olukosi, J.O. \& Erhabor, P.O. (1972). Introduction to Farm Management Economics : Principles and Application.Agitab Publishers Ltd. Zaria, Nigeria.

Tesema, D., \& Berhanu, A. (2018). Rural livelihood strategies and household food security of farmers surrounding Derba cement factory, Oromia Region, Ethiopia Rural Sustainability Research, 40(335), 2-17.

Wadud, A., \& White, B. (2000). Farm household efficiency in Bangladesh: a comparison of stochastic frontier and DEA methods. Applied Economics, 32(13), 1665-1673.

Wijk, M. V., Harmmond, J., Frelat, R., Fraval, S., Teufel, N., Tavenna, K., \& Henderson, B. (2018). Smallholder farmers, food security and livelihood: exploring trade-offs and synergies using Farm Household Characterization data. Conference paper, Science Forum, Stellenbosch, South Africa. 